Article

\title{
Genome Sequencing of Pantoea agglomerans C1 Provides Insights into Molecular and Genetic Mechanisms of Plant Growth-Promotion and Tolerance to Heavy Metals
}

\author{
Francesca Luziatelli ${ }^{1,+}+\mathbb{\infty}$, Anna Grazia Ficca ${ }^{1,+}{ }^{+}$, Mariateresa Cardarelli ${ }^{2} \mathbb{D}$, Francesca Melini ${ }^{3}$, \\ Andrea Cavalieri ${ }^{4}$ (D) and Maurizio Ruzzi ${ }^{1, *(D)}$ \\ 1 Department for Innovation in Biological, Agrofood and Forest systems (DIBAF), University of Tuscia, \\ via C. de Lellis, snc, I-01100 Viterbo, Italy; f.luziatelli@unitus.it (F.L.); ficca@unitus.it (A.G.F.) \\ 2 CREA Research Centre for Vegetable and Ornamental Crops, I-84098 Pontecagnano, Italy; \\ mteresa.cardarelli@crea.gov.it \\ 3 CREA Research Centre for Food and Nutrition, Via Ardeatina 546, I-00178 Rome, Italy; \\ francesca.melini@crea.gov.it \\ 4 Department of Plant and Environmental Sciences, University of Copenhagen, DK-1871 Frederiksberg, \\ Denmark; anca@plen.ku.dk \\ * Correspondence: ruzzi@unitus.it; Tel.: +39-0761-357-317 \\ + These authors contributed equally to this work.
}

Received: 23 November 2019; Accepted: 20 January 2020; Published: 22 January 2020

\begin{abstract}
Distinctive strains of Pantoea are used as soil inoculants for their ability to promote plant growth. Pantoea agglomerans strain C1, previously isolated from the phyllosphere of lettuce, can produce indole-3-acetic acid (IAA), solubilize phosphate, and inhibit plant pathogens, such as Erwinia amylovora. In this paper, the complete genome sequence of strain C1 is reported. In addition, experimental evidence is provided on how the strain tolerates arsenate As (V) up to $100 \mathrm{mM}$, and on how secreted metabolites like IAA and siderophores act as biostimulants in tomato cuttings. The strain has a circular chromosome and two prophages for a total genome of 4,846,925-bp, with a DNA G+C content of $55.2 \%$. Genes related to plant growth promotion and biocontrol activity, such as those associated with IAA and spermidine synthesis, solubilization of inorganic phosphate, acquisition of ferrous iron, and production of volatile organic compounds, siderophores and GABA, were found in the genome of strain $\mathrm{C} 1$. Genome analysis also provided better understanding of the mechanisms underlying strain resistance to multiple toxic heavy metals and transmission of these genes by horizontal gene transfer. Findings suggested that strain $\mathrm{C} 1$ exhibits high biotechnological potential as plant growth-promoting bacterium in heavy metal polluted soils.
\end{abstract}

Keywords: Pantoea agglomerans; plant growth-promotion; Solanum lycopersicum L.; indole-3-acetic acid; siderophores; arsenic resistance; complete genome; horizontal gene transfer

\section{Introduction}

Soils are a natural source of heavy metals (HM), but geologic and anthropogenic activities have increased concentration thereof in soil, water and living systems [1]. Upon rapid and huge HM accumulation, remediation has become necessary to protect the environment from the toxic effects of $\mathrm{HM}$. Several efforts have been thus made so far, to develop sustainable and environment-friendly strategies.

As an adjunct to the various phytoremediation approaches, the possibility of using soil bacteria together with plants has been increasingly explored [2]. These bacteria comprise bio-degradative 
bacteria, plant growth-promoting bacteria (PGPB) and bacteria that facilitate phytoremediation by other means [3].

PGPB enhance the growth of plants through various plant growth-promoting (PGP) traits (e.g., phosphate solubilization, production of indole-3-acetic acid, siderophores, ammonia, hydrogen cyanide and nitrogen fixation) [3-6]. In addition, they have the potential for metal detoxification and mitigation of plant's stress in polluted environment.

Among HM, arsenic needs special attention. This element is included in the list of agents, prepared by the International Agency for Research on Cancer (IARC), for which sufficient evidence of carcinogenicity in humans exists (Group 1; [7]), and is ranked first in the 2017 CERCLA Priority List of the US Agency for Toxic Substances and Disease Registry [8]. For this reason, arsenic contamination of soil and groundwater, originated from natural and anthropogenic sources, can determine a price decline in contaminated agricultural food products. In addition, long-term exposure to arsenic from drinking arsenic-rich water is a great threat to public health [9].

Arsenic and its more than 200 compounds are ubiquitous in the environment and can be classified into three major groups: inorganic arsenic compounds, organic arsenic compounds, and arsine gas [7]. Toxicity depends on the form: soluble inorganic species are more toxic than organic forms, and arsenite (arsenic (III)) is more toxic than arsenate (arsenic (V); [10]). The trivalent and pentavalent forms are the most common oxidation states.

Pathways involved in resistance to both arsenite and arsenate are widely found in different species of Gram-negative and Gram-positive bacteria. Usually, $\mathrm{As}(\mathrm{V})$ is reduced to $\mathrm{As}(\mathrm{III})$ by an intracellular thiol-linked reductase, named ArsC [11], and arsenite is extruded from the cell using efflux proteins (ArsB or Acr3) that can act as proton exchanger, working alone or in conjunction with an intracellular ATPase (ArsA; [12]).

Plants subjected to arsenic have been shown to increase their susceptibility to pathogen infections [13]. In this framework, the combination of biotic and abiotic stress was responsible for a reduction in plant growth and yield. However, when rice plants were treated with selected Pantoea strains, such as EA106, a lower susceptibility to pathogens was observed as well as a lower arsenic uptake, giving the first evidence of an up-regulation of defense-related genes mediated by Pantoea [13]. In parallel, it has been demonstrated that the arsenic resistance gene cluster that confers arsenic resistance through arsenate reduction and arsenite efflux ( $\operatorname{ars} R B C$ or $\operatorname{ars} R B C H$ ) occurs in the genome of several strains belonging to different Pantoea species [14]. Based on these findings, it is important to understand the impact that arsenic tolerant Pantoea strains can have on reducing plant stress and improving plant growth performance.

Pantoea agglomerans is a representative member of Pantoea genus, and comparative genomics allows including P. agglomerans strains into different clades which comprise both clinical and plant-beneficial strains [15]. Some strains are frequently found in association with plant hosts [16], and others are agronomically relevant for their PGP features, exerted also by synthesis of indole-3-acetic acid (IAA), for the biocontrol activity and for their involvement in plant disease management [17]. Sequencing and annotation of the complete genome of plant-beneficial P. agglomerans strains can hence improve understanding of the potential use of these microorganisms as plant biostimulants and can be valuable for the identification of novel plant growth-promoting rhizobacteria (PGPR) to use to maximize the remediation potential of plants.

In the present study, the complete genome sequence of a strain of P. agglomerans (C1 strain) and a comparative genome analysis, specifically focused on PGP traits and heavy metal resistance, are reported. The strain was previously isolated from the phyllosphere of lettuce (Lactuca sativa L.) plants treated with vegetal-derived protein hydrolysates [18]. It showed biocontrol activity against Erwinia amylovora, as well as PGP traits, such as production of auxin-like phytohormones, after being placed in the genus Pantoea by $16 \mathrm{~S}$ rDNA sequencing [19]. Results about experimental inoculation of plants and cultivation in the presence of arsenate and arsenite are also presented, so as to get insights 
into the potential of the P. agglomerans strain C1 to both survive in arsenate-contaminated soil and stimulate plant growth.

\section{Materials and Methods}

\subsection{DNA Extraction, Genome Sequencing, Assembly and Annotation}

Genomic DNA was extracted by using PureLink Genomic DNA Mini Kit and quantified by Qubit ds HS assay kit (Thermo Fisher Scientific Italia, Rodano (MI), Italy), as reported elsewhere [19]. Library preparation and genome sequencing were performed at Bio-Fab Research s.r.l. (Rome, Italy) using the Illumina MiSeq version 3 sequencing platform system in 300-nucleotide (nt) paired-end mode, and run statistics were determined using CLC Genomics Workbench 12 (Qiagen GmbH, Hilden, Germany). The Illumina generated reads were assembled by the A5-myseq assembly pipeline [20], as described in Luziatelli et al. [21]. Gene prediction analysis and functional annotation of the genome were performed by Rapid Annotation by using Subsystems Technology (RAST; [22]), specifically by the RAST Toolkit (RASTtk) option [23] and visualized with the SEED viewer [24].

\subsection{Phylogenetic Tree Construction and ANI}

The phylogenetic tree was constructed from user-selected genomes by the FastTree method [25] using the Phylogenetic Tree Building Service available at the Patric website (https://www.patricbrc.org), with all shared proteins as option and 1000 bootstrap replications. The analysis included: type-strains of major Pantoea species; five strain for each of the two P. agglomerans group; representative strains of $P$. ananatis and P. vagans; Pantoea strains that share a highly similar heavy metal resistance gene cluster; Providencia rettgeri DSM1131, as outgroup. Average nucleotide identity analysis was performed between P. agglomerans C1 and other Pantoea isolates included in the phylogenetic tree, using an on-line ANI calculator [26], and the presence of plasmid replicons or prophages was determined using the PlasmidFinder tool [27] and PHAge Search Tool Enhanced Release (PHASTER) [28,29], respectively.

\subsection{Functional Genome Annotation and Identification of Genomic Islands}

The Cluster of Orthologous Groups (COG) functional categories were assigned through the WebMGA server [30]. Homologs of genes contributing to plant growth promotion were identified with tBLASTn, using target protein sequences from closely related species, and functional genes involved in heavy metal resistance genes were identified by the bidirectional best hit analysis performed in RAST. Putative genomic islands (GI) generated from HGT were detected using IslandViewer 4 [31].

\subsection{Production of Indole-3-Acetic Acid}

To induce production of indole-3-acetic acid (IAA), $1 \mathrm{~mL}\left(\sim 10^{9}\right.$ cells) of an LB-medium overnight culture of strain C1 was transferred into a $100 \mathrm{~mL}$ Erlenmeyer flask containing $20 \mathrm{~mL}$ of LB medium supplemented with sterile-filtered tryptophan $(0.4 \mathrm{mM})$. The liquid culture was grown at $30{ }^{\circ} \mathrm{C}$ in agitation (180 rpm), and cells were separated from the exhausted medium by centrifugation $(10,000 \times g$ for $10 \mathrm{~min}$ ) and discarded after $24 \mathrm{~h}$. The collected supernatant was filtered through a $0.22 \mu \mathrm{m}$ membrane and stored at $-20{ }^{\circ} \mathrm{C}$ for later use. Total IAA was determined by a colorimetric method using Salkowski reagent and authentic IAA (Sigma-Aldrich, St. Louis, MO, USA) as a standard [32].

\subsection{Determination of Siderophore Production}

The siderophore production was detected by the Chrome Azurol-S assay [33], cultivating the microorganism on solid (Chrome Azurol agar, CAS; Merck KGaA, Darmstadt, Germany) or liquid medium (LB with 0.4 mM tryptophan or Fe-deficient King's B medium). On agar plates, production was visualized as an orange halo around the colonies after $48 \mathrm{~h}$ incubation at $30^{\circ} \mathrm{C}$ and was expressed according to the formula

$$
W_{\text {act }}=\left(S_{\mathrm{h}}^{2}\right) /\left(S_{\mathrm{c}}^{*} t\right)
$$


by Hrynkiewicz et al. [34], where $W_{\text {act }}$ is the coefficients of activity, $S_{\mathrm{h}}$ is the diameter of the hydrolysis zone, $S_{\mathrm{c}}$ is the colony diameter, and $t$ is the incubation time.

For quantitative analysis, $0.5 \mathrm{~mL}$ of an LB overnight culture of $P$. agglomerans strain $\mathrm{C} 1$ was transferred to a $250 \mathrm{~mL}$ Erlenmeyer flask containing $50 \mathrm{~mL}$ of the test medium. Cultures were grown at $30^{\circ} \mathrm{C}$ and $180 \mathrm{rpm}$ agitation speed. After 48 hours, cultures were centrifuged at $10,000 \mathrm{rpm}$ for $10 \mathrm{~min}$ and the resulting supernatant was filtered through a $0.22 \mu \mathrm{m}$ pore size.

For siderophore quantification $0.5 \mathrm{~mL}$ of filtered supernatant were mixed with $0.5 \mathrm{~mL}$ of CAS assay solution, prepared as described by Alexander and Zuberer [35]. After reaching the equilibrium (20 min of incubation) the absorbance was measured spectrophotometrically at $630 \mathrm{~nm}$ using a reference containing $0.5 \mathrm{~mL}$ CAS solution with $0.5 \mathrm{~mL}$ uninoculated medium.

Siderophore production is expressed as percentage of siderophore units (PSU), calculated using the following formula:

$$
[(A r-A s) / A r] * 100,
$$

where $A r$ is the Absorbance of reference (CAS assay solution + uninoculated media) and As is the Absorbance of the sample (CAS assay solution + cell-free supernatant).

The experiment was performed in triplicate. In order to avoid iron contamination (on iron-deficient-cultures), all glassware was soaked in $10 \%$ nitric acid, overnight, and, subsequently, washed with deionized water prior to use.

\subsection{Determination of Minimal Inhibitory Concentration of Arsenic}

Minimal inhibitory concentration (MIC) of arsenite (As(III)) and arsenate (As(V)) for P. agglomerans strain $\mathrm{C} 1$ was determined in $20 \mathrm{~mL}$ cultures grown in $100 \mathrm{~mL}$ Erlenmeyer flasks at $30^{\circ} \mathrm{C}$ in agitation (180 rpm). Cultivation was carried out in LB (Lennox) broth amended with sodium arsenite (As(III)) or sodium arsenate $(\mathrm{As}(\mathrm{V}))$ at a concentration between 5 and $50 \mathrm{mM}$. The stock solutions $(200 \mathrm{mM})$ of sodium arsenate $\left(\mathrm{Na}_{2} \mathrm{HAsO}_{4} \cdot 7 \mathrm{H}_{2} 0\right.$; Merck KGaA, Darmstadt, Germany) or sodium arsenite $\left(\mathrm{NaAsO}_{2}\right.$ Merck KGaA, Darmstadt, Germany) were prepared in sterile water. Cultures were inoculated with LB overnight cultures (initial $\mathrm{OD}_{600}$ of 0.1 ), and growth was determined by OD measurement $48 \mathrm{~h}$ after the inoculum. All samples were tested in triplicates and medium without inoculation or medium inoculated with Escherichia coli strain JM109 were used as controls.

\subsection{Plant Inoculation}

Tomato cuttings experiments were carried out as reported previously by Colla et al. [36]. In brief, tomato seeds (Solanum lycopersicum L. cv. Marmande, SAIS Sementi, Cesena, Italy) were sown in moist vermiculite:peat-based substrate (1:1 volume ratio) in a germination tray, and incubated in a growth chamber. The growth chamber was set up to maintain a $16 \mathrm{~h}$ photoperiod with $25^{\circ} \mathrm{C}$ light $/ 18^{\circ} \mathrm{C}$ night and $65 \%$ relative humidity. The average photosynthetic photon flux at the canopy level was $75 \mu \mathrm{mol}$ $\mathrm{m}^{-2} \mathrm{~s}^{-1}$. After two weeks, the tomato seedlings, at a three true leaves stage, were cut at the base of the stem, and the obtained cuttings were dipped for 5 minutes into sterilized distilled water or sterilized distilled water supplemented with fresh LB medium $\left(15 \mathrm{~mL} \mathrm{~L}^{-1}\right)$; overnight culture (spent medium with cells; $15 \mathrm{~mL} \mathrm{~L}^{-1}$ ); filtered supernatant (cell-free spent medium; $15 \mathrm{~mL} \mathrm{~L}^{-1}$ ); indole-3-butyric acid solution (IBA; $500 \mathrm{mg} \mathrm{L}^{-1}$ ). IBA was dissolved in $\mathrm{NaOH}(1 \mathrm{M})$ and diluted in water to a final stock concentration of $1 \mathrm{~g} \mathrm{~L}^{-1}$. After treatment, seedlings were transplanted directly into plastic pots containing $8 \mathrm{~cm}$ of wetted perlite, as rooting medium, and, 15 days after planting, tomato cuttings were separated into shoots and roots. Roots were kindly washed with distilled water, to remove any perlite particles, and determination of root surface was done by using WinRHIZO Pro (Regent Instruments Inc., Quebec, Canada), connected to a STD4800 scanner. Ten cuttings were used for each treatment, and results were the mean value of three replicates for each treatment (with a total of 30 plants per treatment). 


\subsection{Statistical Analysis}

Differences between treatment groups were compared using One-way analysis of variance (ANOVA) test, followed by Tukey's honestly significant difference (HSD) test with significance set at $p<0.05$.

\subsection{Nucleotide Sequence Accession Number}

The genome sequence of P. agglomerans C1 is available under NCBI BioProject PRJNA523737, with GenBank accession number SMLN00000000.1 and Sequence Read Archive (SRA) accession number SRP212904.

Accession numbers of the genomes used for phylogenetic analysis are reported in Supplementary Table S1.

\section{Results and Discussion}

\subsection{Genome Sequencing and Comparison with Pantoea Genomes}

In order to investigate the genomic features associated with strain $\mathrm{C} 1$, the whole genome was sequenced using Illumina MiSeq (300-bp paired end) technology [21]. As reported before, the complete genome consisted of one circular chromosome of 4,846,925-bp, with a GC content of 55.2\% [21]. Building the reference sequence, NCBI re-annotated the C1 genome using NCBI Prokaryotic Genome Annotation Pipeline (GeneBank reference: SMLN00000000.1), which allowed us to re-estimate the number of genes, coding sequences, rRNAs and ncRNAs present in this genome (Table 1).

Table 1. General features of P. agglomerans C1 genome.

\begin{tabular}{ccc}
\hline Species & Pantoea agglomerans & Source \\
\hline Strain & $\mathrm{C} 1$ & \\
Assembly level & Contig & \\
No. of sequences & 22 & {$[21]$} \\
Genome size (bp) & $4,846,925$ & {$[21]$} \\
GC content (\%) & 55.2 & {$[21]$} \\
Gene & 4601 & This work \\
CDS & 4497 & This work \\
RNA & 104 & This work \\
rRNA (5S,16S,23S) & $9,6,9$ & This work \\
Completed (5S,16S,23S) & $9,1,1$ & This work \\
Truncated (16S,23S) & 5,8 & This work \\
tRNA & 70 & {$[21]$} \\
ncRNA & 10 & This work \\
Prophage & 2 & This work \\
Genomic island (integrated method) & $11>20,000 \mathrm{bp}$ & This work \\
\hline
\end{tabular}

In agreement with data from agarose gel electrophoresis analysis of total genomic DNA, no plasmid was detected by using PlasmidFinder [27]. In contrast, a computer search by PHASTER [28,29] revealed the presence of two distinct large intact prophage regions exhibiting similarity with phages from Erwinia amylovora (ENT90; GenBank No. NC_019932) and Salmonella enterica serovar Enteritidis LK5 (RE_2010; GenBank No. HM770079) [21]. It is interesting to highlight that selected P. agglomerans strains (i.e., EH21-5) can be successfully utilized to develop effective phage therapies against plant pathogens, such as E. amylovora [37].

Whole-genome phylogenetic analysis revealed that strain C1 clustered in the same clade which includes P. agglomerans type strain DSM3493 (Figure 1). 


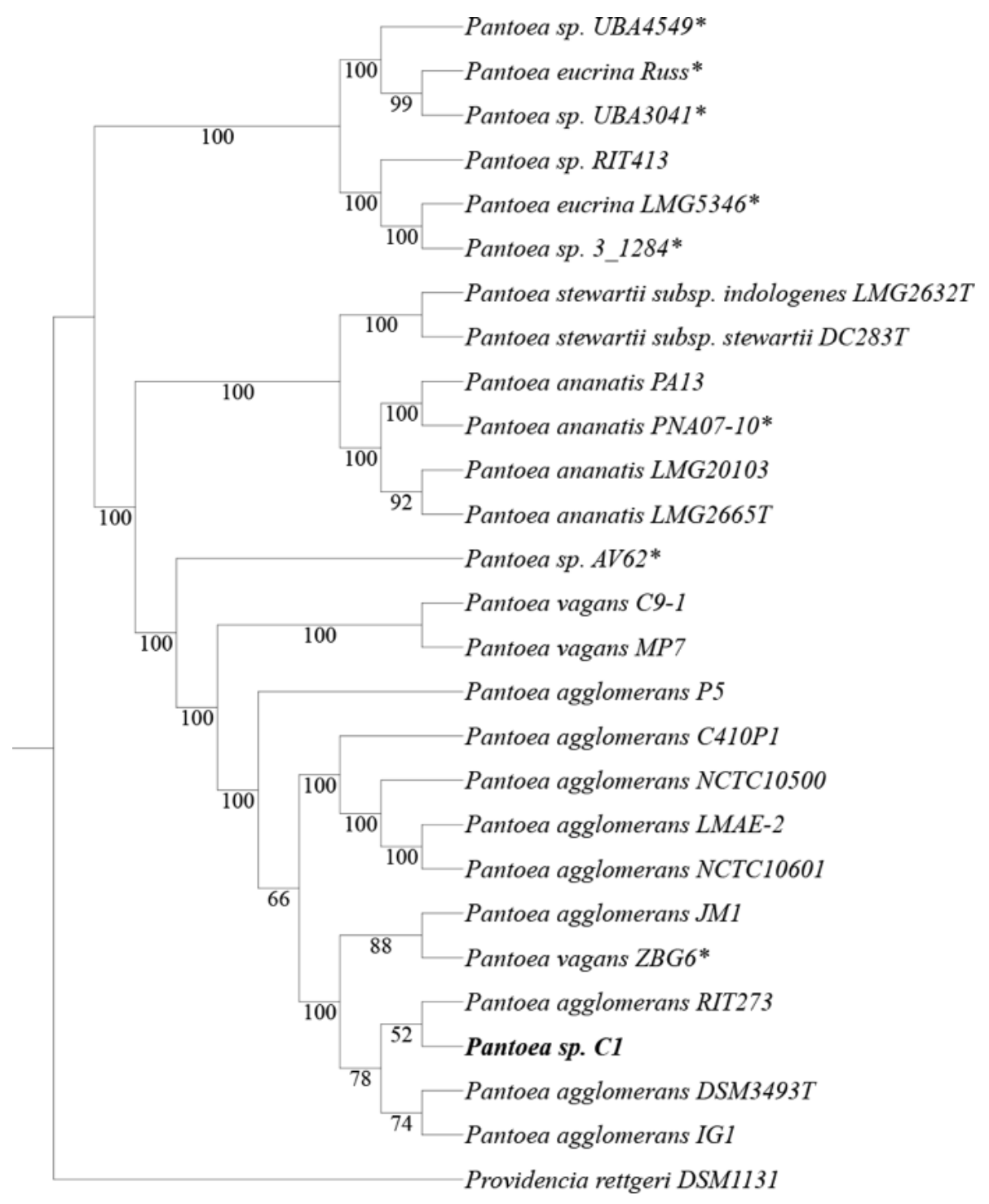

Figure 1. Comparison analysis of strain $\mathrm{C} 1$ with other 25 Pantoea strains. The phylogenetic tree was built from user-selected genomes by the FastTree method [25]. Branch labels represent bootstrap support (in percent; 1000 bootstrap replicates). T indicates type strain; the asterisk (*) indicates Pantoea strains that share a highly similar heavy metal resistance gene cluster (see Figure 3). Providencia rettgeri DSM1131 was used as outgroup. Accession numbers are reported in Supplementary Table S1.

The relationships obtained using the distance approach, based on the Average Nucleotide Identity (ANI), were congruent with the species tree showed in Figure 1; the similarity between genomes of strain C1 and P. agglomerans type strain DSM3493 and other P. agglomerans strains was about $99 \%$ (Table 2).

Based on these data, the strain can be reclassified as P. agglomerans C1. All the data also indicated that strain ZBG6 should belong to the species P. agglomerans rather than P. vagans, as formerly proposed (Figure 1).

Exploitation of strain $\mathrm{C} 1$ genome with IslandViewer 4 revealed the presence of 29 putative genomic islands (supplementary Figure S1), eleven of which had a size higher than 20,000 bp and whose reliability was supported by three different computational methods. Interestingly, a total of 9 out of the aforesaid 11 GI harbor phage- or mobile-related coding sequence (Table S2). 
Table 2. Average Nucleotide Identity (ANI) values (in percentages) based on alignment of the whole genome of strain C1 and the most closely related members of the genus Pantoea.

\begin{tabular}{|c|c|c|c|c|c|c|c|c|c|c|c|c|c|c|c|c|}
\hline CODE & STRAIN & 1 & 2 & 3 & 4 & 5 & 6 & 7 & 8 & 9 & 10 & 11 & 12 & 13 & 14 & 15 \\
\hline 1 & Strain $\mathrm{C} 1$ & * & 98.7 & 98.7 & 98.7 & 98.6 & 97.8 & 97.3 & 84.0 & 84.1 & 84.2 & 84.3 & 84.1 & 91.3 & 91.3 & 98.7 \\
\hline 2 & Pantoea agglomerans RIT273 & 98.7 & $*$ & 98.7 & 98.7 & 98.7 & 97.9 & 97.3 & 84.0 & 84.0 & 84.0 & 84.1 & 84.1 & 91.3 & 91.3 & 98.8 \\
\hline 3 & Pantoea agglomerans DSM $3463^{\mathrm{T}}$ & 98.7 & 98.7 & * & 98.7 & 98.7 & 97.9 & 97.3 & 84.1 & 84.0 & 84.0 & 83.9 & 84.1 & 91.3 & 91.4 & 98.7 \\
\hline 4 & Pantoea agglomerans JM1 & 98.7 & 98.7 & 98.7 & * & 98.7 & 97.8 & 97.3 & 84.0 & 84.0 & 84.0 & 83.9 & 84.1 & 91.3 & 91.3 & 98.8 \\
\hline 5 & Pantoea agglomerans IG1 & 98.6 & 98.7 & 98.7 & 98.7 & $*$ & 97.8 & 97.2 & 83.9 & 83.9 & 83.9 & 83.9 & 84.0 & 91.3 & 91.3 & 98.7 \\
\hline 6 & Pantoea agglomerans C410P1 & 97.8 & 97.9 & 97.9 & 97.8 & 97.8 & $*$ & 97.5 & 84.0 & 84.1 & 83.9 & 83.9 & 84.1 & 91.8 & 91.8 & 97.9 \\
\hline 7 & Pantoea agglomerans P5 & 97.3 & 97.3 & 97.3 & 97.3 & 97.2 & 97.5 & $*$ & 83.9 & 84.0 & 84.0 & 83.9 & 84.0 & 91.2 & 91.3 & 97.3 \\
\hline 8 & Pantoea ananatis LMG $2665^{\mathrm{T}}$ & 84.0 & 83.9 & 84.1 & 84.0 & 83.9 & 84.0 & 83.9 & $*$ & 99.3 & 99.2 & 83.9 & 86.0 & 84.1 & 84.2 & 84.0 \\
\hline 9 & Pantoea ananatis LMG20103 & 84.0 & 84.0 & 84.0 & 84.0 & 83.9 & 84.1 & 84.0 & 99.3 & * & 99.2 & 83.8 & 85.9 & 84.2 & 84.2 & 83.9 \\
\hline 10 & Pantoea ananatis PNA 07-10 & 84.2 & 84.0 & 84.0 & 84.0 & 83.9 & 83.9 & 84.0 & 99.2 & 99.2 & * & 84.2 & 85.9 & 84.2 & 84.0 & 84.2 \\
\hline 11 & Pantoea eucrina LMG5346 ${ }^{\mathrm{T}}$ & 84.3 & 84.1 & 84.0 & 83.9 & 83.9 & 83.9 & 83.9 & 83.9 & 83.8 & 84.2 & * & 84.0 & 83.8 & 83.8 & 84.2 \\
\hline 12 & Pantoea stewartii sub. stewartii $\mathrm{DC} 283^{\mathrm{T}}$ & 84.1 & 84.1 & 84.1 & 84.1 & 84.0 & 84.1 & 84.0 & 86.0 & 85.9 & 85.9 & 84.0 & $*$ & 84.2 & 84.1 & 84.0 \\
\hline 13 & Pantoea vagans C9-1 & 91.3 & 91.3 & 91.3 & 91.3 & 91.3 & 91.8 & 91.2 & 84.1 & 84.2 & 84.2 & 83.8 & 84.2 & * & 96.9 & 91.3 \\
\hline 14 & Pantoea vagans MP7 & 91.3 & 91.3 & 91.4 & 91.3 & 91.3 & 91.8 & 91.3 & 84.1 & 84.2 & 84.0 & 83.8 & 84.1 & 96.9 & * & 91.3 \\
\hline 15 & Pantoea vagans ZBG6 & 98.7 & 98.8 & 98.7 & 98.8 & 98.7 & 97.9 & 97.3 & 84.0 & 83.9 & 84.3 & 84.2 & 84.0 & 91.3 & 91.3 & $*$ \\
\hline
\end{tabular}

${ }^{\mathrm{T}}$ Type-strain. ${ }^{*}=100$. 


\subsection{Plant Beneficial Properties of Pantoea agglomerans $C 1$}

The protein-encoding genes (PEGs) predicted using RASTtk were classified into 18 functional categories based on COG of proteins [38]. As shown in Table 3, most of the genes were associated with functions, such as transcription $(\mathrm{K} ; 8.71 \%)$, amino acid transport and metabolism $(\mathrm{E} ; 8.33 \%)$, inorganic ion transport and metabolism $(\mathrm{P} ; 6.11 \%)$, carbohydrate transport and metabolism $(\mathrm{G} ; 5.88 \%)$, and cell wall/membrane/envelop biogenesis (M; 5.43\%).

Table 3. Number of genes associated with general Clusters of Orthologous Groups (COG) functional categories.

\begin{tabular}{|c|c|c|c|c|}
\hline Function & Code & Value & \%age & Description \\
\hline & $\mathrm{D}$ & 62 & 1.32 & Cell cycle control, cell division, chromosome partitioning \\
\hline & M & 255 & 5.43 & Cell wall/membrane/envelope biogenesis \\
\hline CELLULAR & $\mathrm{N}$ & 95 & 2.02 & Cell motility \\
\hline PROCESSES AND & $\mathrm{O}$ & 107 & 2.28 & Post-translational modification, protein turnover, and chaperones \\
\hline \multirow[t]{4}{*}{ SIGNALING } & $\mathrm{T}$ & 106 & 2.26 & Signal transduction mechanisms \\
\hline & $\mathrm{U}$ & 54 & 1.15 & Intracellular trafficking, secretion, and vesicular transport \\
\hline & $\mathrm{V}$ & 47 & 1.00 & Defense mechanisms \\
\hline & A & 0 & 0.00 & RNA processing and modification \\
\hline INFORMATION & B & 0 & 0.00 & Chromatin structure and dynamics \\
\hline STORAGE AND & $\mathrm{J}$ & 193 & 4.11 & Translation, ribosomal structure and biogenesis \\
\hline \multirow[t]{2}{*}{ PROCESSING } & $\mathrm{K}$ & 409 & 8.71 & Transcription \\
\hline & $\mathrm{L}$ & 158 & 3.36 & Replication, recombination and repair \\
\hline \multirow{8}{*}{ METABOLISM } & $\mathrm{C}$ & 234 & 4.98 & Energy production and conversion \\
\hline & $\mathrm{E}$ & 391 & 8.33 & Amino acid transport and metabolism \\
\hline & $\mathrm{F}$ & 106 & 2.26 & Nucleotide transport and metabolism \\
\hline & G & 276 & 5.88 & Carbohydrate transport and metabolism \\
\hline & $\mathrm{H}$ & 176 & 3.75 & Coenzyme transport and metabolism \\
\hline & I & 113 & 2.41 & Lipid transport and metabolism \\
\hline & $\mathrm{P}$ & 287 & 6.11 & Inorganic ion transport and metabolism \\
\hline & Q & 39 & 0.83 & Secondary metabolites biosynthesis, transport, and catabolism \\
\hline POORLY & $\mathrm{R}$ & 0 & 0.00 & General function prediction only \\
\hline \multirow[t]{2}{*}{ CHARACTERIZED } & $\mathrm{S}$ & 937 & 19.95 & Function unknown \\
\hline & - & 651 & 13.86 & Not in COGs \\
\hline
\end{tabular}

Nearly one-third of the entire set of genes encoding proteins cannot be annotated with a known function (Table 3).

Functional analysis of P. agglomerans $\mathrm{C} 1$ genome showed the presence of several genes contributing directly or indirectly to PGP and biocontrol activities (Table 4).

We identified the genes encoding key enzymes involved in the synthesis and secretion of IAA through the IPyA (ipdC) and the IAM (amiE) pathways [39]. In P. agglomerans C1 genome, we also found two operons (spe $A B$ and speDE) that could be involved in spermidine biosynthesis, a class of compounds that are essential for eukaryotic cells viability and have been correlated with lateral root development, pathogen resistance, and alleviation of oxidative, osmotic and acidic stresses [40]. The annotation study also revealed the presence of several gene clusters involved in mineral phosphate solubilization, including the genes encoding PQQ-dependent glucose dehydrogenase $(g c d)$, membrane-bound gluconate-2-dehydrogenase (gad) and phosphatase-specific transport system (Table 3) [41,42].

As regards the indirect means of plant growth promotion, in P. agglomerans $\mathrm{C} 1$ genome, we found (Table 4) genes encoding enzymes involved in the synthesis of volatile organic compounds (acetoin and 2,3-butanediol; [43,44], Gamma-Aminobutyric Acid (GABA) [45], and siderophores [46], as well as genes encoding the three components of EfeUOB transporter, a ferrous iron transporter induced by low $\mathrm{pH}$ and low iron [47]. 
Table 4. Genes potentially associated with Plant Growth-Promotion traits in P. agglomerans C1.

\begin{tabular}{|c|c|c|c|}
\hline \multicolumn{4}{|c|}{ Direct Plant Growth-Promotion } \\
\hline Gene & EC No. & Annotation & $\begin{array}{l}\text { Gene Location, Coding } \\
\text { Strand }(+/-)\end{array}$ \\
\hline \multicolumn{4}{|c|}{ IAA production } \\
\hline$i p d C$ & 4.1.1.74 & Indole-3-pyruvate decarboxylase & Contig1: 2029913-2028261, - \\
\hline amiE & 3.5.1.4 & Aliphatic amidase & Contig1: 254208-254999, + \\
\hline aec & & Auxin efflux carrier family protein & Contig1: 1779607-1780566, + \\
\hline \multicolumn{4}{|c|}{ Spermidine biosynthesis } \\
\hline speA & 3.5.3.11 & Agmatinase & Contig4: 165937-1659017, - \\
\hline speB & 4.1.1.19 & Biosynthetic arginine decarboxylase & Contig4: 168083-1686107,- \\
\hline speD & 4.1.1.50 & S-adenosylmethionine decarboxylase proenzyme & Contig3: 73489-74298, + \\
\hline speE & 2.5.1.16 & prokaryotic class $1 \mathrm{~A}$ Spermidine synthase & Contig3: 73489-74298, + \\
\hline \multicolumn{4}{|c|}{ Phosphate solubilization } \\
\hline gad & 1.1.99.3 & Gluconate 2-dehydrogenase, membrane-bound, cytochrome c & Contig3: 303092-301830, - \\
\hline gad & 1.1 .99 .3 & Gluconate 2-dehydrogenase, membrane-bound, flavoprotein & Contig3: 304866-303097, - \\
\hline gad & 1.1.99.3 & Gluconate 2-dehydrogenase, membrane-bound, gamma subunit & Contig3: 305631-304903,- \\
\hline gad & 1.1.99.3 & Gluconate 2-dehydrogenase, membrane-bound, cytochrome c & Contig3: 495485-494175, - \\
\hline gad & 1.1.99.3 & Gluconate 2-dehydrogenase, membrane-bound, flavoprotein & Contig3: 497280-495496, - \\
\hline gad & 1.1 .99 .3 & Gluconate 2-dehydrogenase, membrane-bound, gamma subunit & Contig3: 498017-497283,-- \\
\hline gcd & 1.1.5.2 & Glucose dehydrogenase pyrroloquinoline quinone (PQQ)-dependent & Contig3: 476263-478653, + \\
\hline$p q q$ & & Coenzyme PQQ synthesis protein $\mathrm{B}, \mathrm{C}, \mathrm{D}, \mathrm{E}, \mathrm{F}$ & Contig1: 1076330-1081693, + \\
\hline phou & & Phosphate transport system regulatory protein & Contig6: 207107-206373, - \\
\hline$p s t B$ & & Phosphate transport ATP-binding protein & Contig6: 207898-207125, - \\
\hline pstA & & Phosphate transport system permease protein & Contig6: 208833-207943, - \\
\hline pstC & & Phosphate transport system permease protein & Contig6: 209792-208830,- \\
\hline psts & & Phosphate $A B C$ transporter, periplasmic phosphate-binding protein & Contig6: 210923-209880,- \\
\hline \multicolumn{4}{|c|}{ Indirect Plant Growth-Promotion } \\
\hline Gene & EC No. & Annotation & $\begin{array}{l}\text { Gene Location, Coding } \\
\text { Strand }(+/-)\end{array}$ \\
\hline \multicolumn{4}{|c|}{ Volatile organic compounds (VOCs) } \\
\hline alsR & & Transcriptional regulator of alpha-acetolactate operon & Contig7: 135886-136791, + \\
\hline alsD & 4.1.1.5 & Alpha-acetolactate decarboxylase & Contig7: 135781-134999, - \\
\hline alsS & 2.2.1.6 & Acetolactate synthase & Contig7: 134984-133305, - \\
\hline$b d h$ & 1.1.1.41.1.1.304 & $\begin{array}{l}\text { 2,3-butanediol dehydrogenase, S-alcohol forming, } \\
\text { (R)-acetoin-specific/Acetoin (diacetyl) reductase }\end{array}$ & Contig7: 133283-132510, - \\
\hline & & GABA production & \\
\hline$g a b D$ & 1.2.1.16 & Succinate-semialdehyde dehydrogenase $\left[\mathrm{NAD}(\mathrm{P})^{+}\right]$ & Contig4: 449240-447789, - \\
\hline$g a b T$ & 2.6.1.19 & Gamma-aminobutyrate:alpha-ketoglutarate aminotransferase & Contig2: $419393-420679,+$ \\
\hline \multicolumn{4}{|c|}{ Siderophores biogenesis } \\
\hline fes & & Enterobactin esterase & Contig3: 384712-385917, + \\
\hline ent $A$ & 1.3.1.28 & 2,3-dihydro-2,3-dihydroxybenzoate dehydrogenase & Contig3: 399161-399919, + \\
\hline ent $B$ & 3.3.2.1 & Isochorismatase & Contig3: 398310-399164, + \\
\hline entC & 5.4.4.2 & Isochorismate synthase & Contig3: 395486-396664, + \\
\hline entE & 2.7.7.58 & 2,3-dihydroxybenzoate-AMP ligase & Contig3: 396675-398291, + \\
\hline entF & 6.3.2.14 & Enterobactin synthetase component $\mathrm{F}$ & Contig3: $386228-390157,+$ \\
\hline fepA & & $\begin{array}{l}\text { TonB-dependent receptor; Outer membrane receptor for ferric enterobactin } \\
\text { and colicins B, D }\end{array}$ & Contig3: 384461-382194, - \\
\hline fерв $B$ & & Ferric enterobactin-binding periplasmic protein & Contig3: 395308-394340, - \\
\hline $\mathrm{fepC}$ & & Ferric enterobactin transport ATP-binding protein & Contig3: 390992-390201, - \\
\hline fepD & & Ferric enterobactin transport system permease protein & Contig3: 392922-391966, - \\
\hline fepG & & Ferric enterobactin transport system permease protein & Contig3: 391969-390989, - \\
\hline ents & & Enterobactin exporter & Contig3: 393083-394345, - \\
\hline$y b d z$ & & Putative cytoplasmic protein $\mathrm{YbdZ}$ in enterobactin biosynthesis operon & Contig3: 386017-386235, + \\
\hline fhuA & & Ferric hydroxamate outer membrane receptor & Contig3: 51852-49651, - \\
\hline fhuC & & Ferric hydroxamate ABC transporter, ATP-binding protein & Contig3: 49611-48817, - \\
\hline$f h u D$ & & Ferric hydroxamate $A B C$ transporter, periplasmic substrate binding protein & Contig3: 48806-47928, - \\
\hline fhuB & & Ferric hydroxamate $\mathrm{ABC}$ transporter, permease component & Contig3: 47928-45949, - \\
\hline \multicolumn{4}{|c|}{ Ferrous iron transporter (EfeUOB) } \\
\hline efeU & & Ferrous iron transport permease & Contig1: 1504038-1503214, - \\
\hline$e f e O$ & & Ferrous iron transport periplasmic protein contains peptidase-M75 domain & Contig1: 1504038-1503214, - \\
\hline$e f e B$ & & Ferrous iron transport peroxidase & Contig1: 1503155-1502046, - \\
\hline
\end{tabular}




\subsection{Effects of Pantoea Agglomerans C1 Cells and Metabolites on Root Growth}

Strain $\mathrm{C} 1$ produced siderophores in both solid and liquid medium. Production on CAS agar medium was visualized in an orange halo around the colony, with a coefficient of activity $\left(W_{\text {act }}\right)$ of $0.21 \pm 0.1$. The highest siderophores production in liquid medium was obtained on King's B after $48 \mathrm{~h}$ incubation (11 $\pm 0.5 \mathrm{PSU})$. However, the production of IAA was very limited in this medium, even in the presence of tryptophan (about $20 \pm 1 \mathrm{mg}$ of IAA for liter). In contrast, strain C1 produced IAA up to $150 \pm 5 \mathrm{mg} / \mathrm{L}$ and siderophores up to $4.5 \pm 0.5$ PSU in LB supplemented with tryptophan $(4 \mathrm{mM})$. For this reason, all experiments with tomato plants were carried out using cells and secreted metabolites from cultures grown in LB medium with tryptophan. Treatment of tomato shoots with the spent medium containing cells and secreted metabolites enabled a significant increase in root surface area, 2-weeks after application, with respect to the control shoots treated with distilled water (Figure 2, panel A).
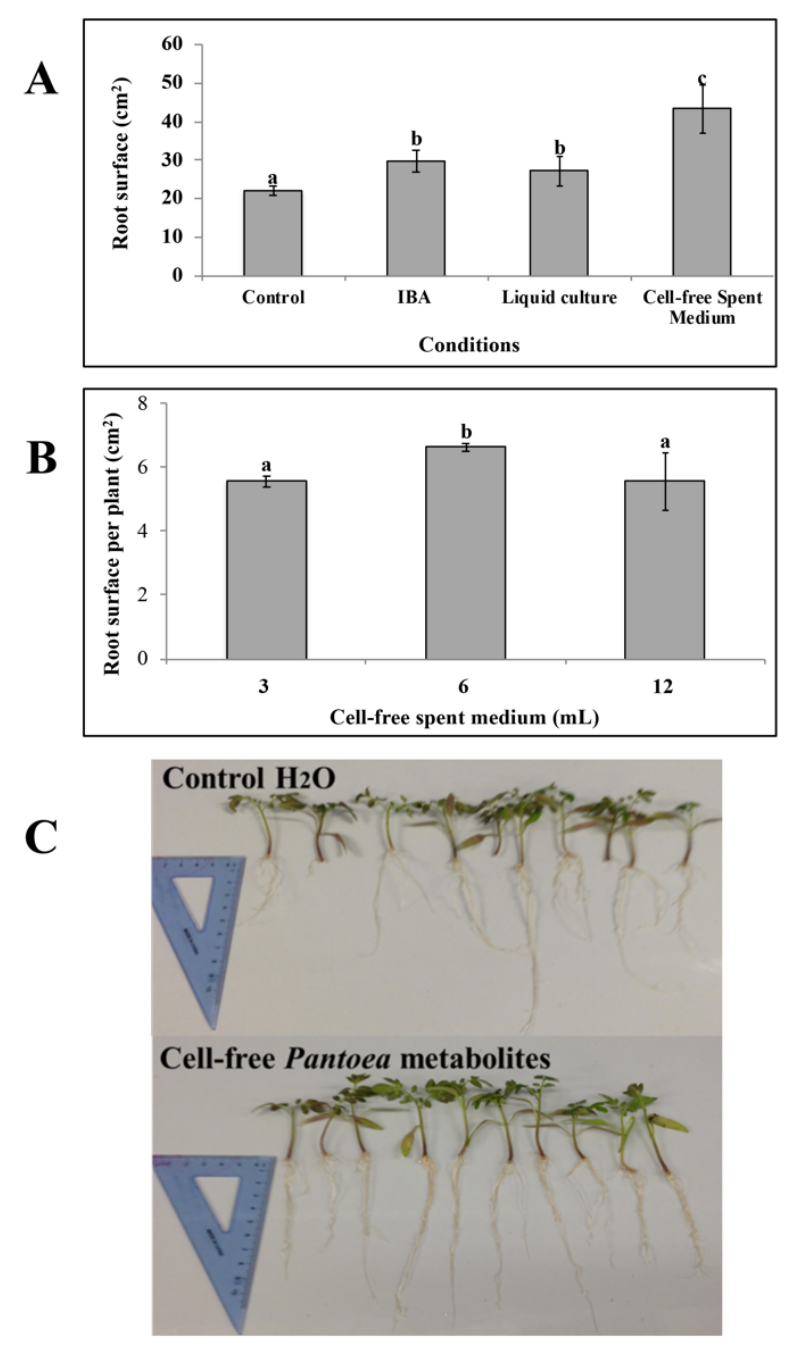

Figure 2. C Effect of P. agglomerans $\mathrm{C} 1$ and its metabolites on the root characteristics of tomato (Solanum lycopersicum L.) cuttings. (A): Effect of C1 culture (spent medium with cells), C1 metabolites (cell-free spent medium) and indole-3-butyric acid solution (IBA) application on total root surface of tomato cuttings 2-weeks after treatment. (B): Dose response showing the effect of $\mathrm{C} 1$ metabolites application on total root surface of tomato cuttings 2-weeks after treatment with 3, 6 or $12 \mathrm{~mL} / \mathrm{L}$ of cell-free P. agglomerans C1 metabolites. (C): Differences of root abundance and appearance of tomato cuttings 2-weeks after immersion in a solution containing 0 (Control) or $6 \mathrm{~mL} / \mathrm{L}$ of cell-free P. agglomerans $\mathrm{C} 1$ metabolites. The spent medium with cells and the cell-free spent medium contained an IAA concentration of $105 \pm 10 \mu \mathrm{g} \mathrm{mL}^{-1}$. Each data point is the mean $\pm \mathrm{SE}$ of 10 replicates. Values with no letter in common significantly differ at $p<0.05$ (Tukey HSD test). 
This effect was comparable to that obtained in IBA-treated shoots (Figure 2, panel A). In contrast, treatment of tomato shoots with fresh LB medium had no effect on root growth compared to control shoots, thus indicating that this stimulatory effect was not dependent upon LB medium components.

When the cell-free supernatant collected from these cultures was used, the increase in root growth was even more remarkable (2-folds compared to water control and 1.45-fold compared to commercial IBA; Figure 2, panel A). The overall effect was found to be dose-dependent and, at higher doses, the increase in root surface was less pronounced (Figure 2, panel B).

Visual inspection of seedlings also indicated that application of strain C1 extracellular metabolites determined an increase in the number and length of major roots of tomato cuttings (Figure 2, panel C). These in vivo experiments clearly demonstrate that strain C1 produces metabolites that promote plant growth.

These results allow inferring that metabolites produced in vitro by strain C1 efficiently act as biostimulants. Although the biotechnological use of beneficial Pantoea strains is generally hampered by biosafety concerns, arising from clinical evidences that some strains are opportunistic human pathogens, and discrimination between clinical and plant beneficial strains cannot be achieved by phylogenetic analysis $[17,48]$, this study shows that it can be taken advantage of the plant growth-promoting properties of the strain $\mathrm{C} 1$. A direct inoculation of the plant with bacterial cells and the release of the strain in the environment can be avoided. The results expand the range of potential applications of strain C1 and allow the development of novel biostimulants with low environmental impact, as well as the avoidance of the known problems related to competition between bioinoculants and soil-plant microbiome.

In vitro assays, performed in collaboration with IRBM Scientific Park (Pomezia, Italy), for testing cytotoxic activity of cell-free supernatant obtained from C1 cultures showed no anti-proliferative effect on HeLa cells, providing preliminary evidence of the biosafety of strain C1 extracellular metabolites.

\subsection{Tolerance to Heavy Metals in Pantoea Agglomerans C1}

In P. agglomerans C1 genome we also found, distributed on different contigs, a number of genes related to resistance to toxic metals, including arsenic, copper and cadmium (Table 5).

For arsenical resistance, we identified three different gene clusters: $\operatorname{ars} R H$, $\operatorname{ars} R B C$, and $\operatorname{ars} R-a c r 3$. The first cluster $(\operatorname{ars} R H)$ contains genes encoding a putative repressor (ArsR) and an NAD(P)H-dependent FMN reductase (ArsH) involved in the oxidation of arsenite to arsenate [49]. The $\operatorname{ars} R B C$ operon encodes a trans-acting transcriptional repressor protein (ArsR), belonging to the $\mathrm{SmtB} /$ ArsR family of metalloregulatory proteins, a putative arsenite antiporter (ArsB), and an arsenate reductase (ArsC) that reduces arsenate to arsenite [50]. The last operon ( $\operatorname{ars} R-a c r 3)$, which is located in pro-phage_2, encodes for a putative transcription factor (ArsR), belonging to the metalloregulator SmtB/ArsR family, and an arsenite efflux pump (Acr3), belonging to ACR3 family [51].

Independent cue (copper efflux), cus (copper sensing) and pco (copper resistance) systems and accessory genes, which confer copper tolerance in bacteria, were also present (Table 5). The cueR-copA gene cluster encodes a putative copper-exporting P-type ATPase (CopA) and a two-component signal transduction system (CusR/CusS), involved in maintaining metal ion homeostasis, which activates, under anaerobic conditions, the expression of the cusCFBA operon in response to elevate concentration of copper [52]. The last set of genes includes homologues to the copper-inducible copABCD and pcoRS gene cluster encoding a two-component regulatory system (PcoR/PcoS) and four structural proteins including an inner membrane protein (CopD), an outer membrane protein (CopB) and two periplasmic proteins (CopA, CopC; [53]. CopA is a multi-copper oxidase protein, responsible for the oxidation of $\mathrm{Cu}(\mathrm{I})$ in the periplasmic space, which confers high resistance to copper [54].

We also identified two genes $(c z c A$ and $c z c C)$ encoding a putative cadmium resistance protein (CzcA) and an RND efflux outer membrane protein (CzcC), respectively (Table 5). These genes belong to the $c z c$ efflux system and are involved in $\mathrm{Cu} / \mathrm{Zn} / \mathrm{Co}$ detoxification in many bacteria [55]. 
Table 5. Genes for tolerance against heavy metal toxicity in P. agglomerans C1.

\begin{tabular}{|c|c|c|c|}
\hline Gene & EC No. & Annotation & $\begin{array}{l}\text { Gene Location, Coding } \\
\text { Strand }(+/-)\end{array}$ \\
\hline \multicolumn{4}{|c|}{ Arsenic tolerance } \\
\hline \multicolumn{4}{|c|}{ arsRH } \\
\hline $\operatorname{ars} R$ & & Arsenical resistance operon repressor & Contig2: 346889-347179,+ \\
\hline $\operatorname{arsH}$ & & Arsenic resistance protein ArsH & Contig2: 347176-347898, + \\
\hline \multicolumn{4}{|c|}{$\operatorname{arsRBC}$} \\
\hline $\operatorname{ars} R$ & & Arsenical resistance operon repressor & Contig2: 350170-349817, - \\
\hline $\operatorname{ars} B$ & & Arsenic efflux pump protein & Contig2: 349720-348437,- \\
\hline $\operatorname{arsC}$ & 1.20.4.1 & $\begin{array}{l}\text { Arsenate reductase glutaredoxin-coupled, } \\
\text { Glutaredoxin-like family }\end{array}$ & Contig2: 348387-347959, - \\
\hline \multicolumn{4}{|c|}{ arsR-acr3 } \\
\hline $\operatorname{ars} R$ & & Arsenical resistance operon repressor & Contig9: 2594-2229, - \\
\hline acr3 & & Arsenical-resistance protein ACR3 & Contig9: $2180-1200,-$ \\
\hline \multicolumn{4}{|c|}{ Copper tolerance } \\
\hline \multicolumn{4}{|c|}{ cueR-copA } \\
\hline cueR & & Transcriptional regulator, MerR family & Contig1: 198563-198967, + \\
\hline $\operatorname{cop} A$ & $\begin{array}{l}3.6 .3 .3 \\
7.2 .2 \cdot 12 \\
7.2 .2 .9\end{array}$ & $\begin{array}{l}\text { Lead, cadmium, zinc and mercury transporting ATPase } \\
\text { Copper-translocating P-type ATPase }\end{array}$ & Contig1: 195952-198465, - \\
\hline \multicolumn{4}{|c|}{ cueR-copA } \\
\hline cueR & & Transcriptional regulator, MerR family & Contig2: 350890-350432, - \\
\hline $\operatorname{cop} A$ & $\begin{array}{l}3.6 .3 .3 \\
7.2 .2 \cdot 12 \\
7.2 .2 .9\end{array}$ & $\begin{array}{l}\text { Lead, cadmium, zinc and mercury transporting ATPase } \\
\text { Copper-translocating P-type ATPase }\end{array}$ & Contig2: 350970-353627, + \\
\hline \multicolumn{4}{|c|}{ copABCD_pcoRS } \\
\hline $\operatorname{cop} A$ & & Multicopper oxidase & Contig2: 364520-366361, + \\
\hline $\operatorname{cop} B$ & & Copper resistance protein CopB & Contig2: 366396-367349, + \\
\hline $\operatorname{cop} C$ & & Copper resistance protein CopC & Contig2: 367381-367761, + \\
\hline $\operatorname{cop} D$ & & Copper resistance protein CopD & Contig2: 367766-368698, + \\
\hline pcoR & & Transcriptional regulator PcoR & Contig2: 368730-369410, + \\
\hline$p \cos$ & 2.7.13.3 & Sensory protein kinase PcoS & Contig2: 369407-370816, + \\
\hline \multicolumn{4}{|c|}{ Cadmium tolerance } \\
\hline \multicolumn{4}{|c|}{ cusCFBA_cusSR } \\
\hline cusC & & Cation efflux system protein CusC & Contig2: 360131-358746, - \\
\hline cusF & & Cation efflux system protein CusF & Contig2: 358717-358364, - \\
\hline cus $B$ & & $\begin{array}{l}\text { Cobalt/zinc/cadmium efflux RND transporter, } \\
\text { Membrane fusion protein, } \\
\text { CzcB family }\end{array}$ & Contig2: 358250-356958, - \\
\hline cusA & & Cation efflux system protein & Contig2: 356947-357380, - \\
\hline cusR & & $\begin{array}{l}\text { Copper-sensing two-component system response } \\
\text { regulator CusR }\end{array}$ & Contig2: 360326-361009, + \\
\hline cusS & & Copper sensory histidine kinase CusS & Contig2: 360999-362453,+ \\
\hline \multicolumn{4}{|c|}{$c z c A C$} \\
\hline$c z c A$ & & Cobalt-zinc-cadmium resistance protein CzcA & Contig2: 504650-501588, - \\
\hline$c z c \mathrm{C}$ & & Probable $\mathrm{Co} / \mathrm{Zn} / \mathrm{Cd}$ efflux system membrane fusion protein & Contig2: 505738-504650,- \\
\hline
\end{tabular}


Interestingly, most of the genes involved in tolerance against heavy metals are clustered in a 23.9- $\mathrm{Kb}$ region on contig 2 (endpoints: 346889-370816; Table 5) and are included in one of the GI supported by all computational methods of IslandViewer 4 (Figure S1). A genome-mining analysis showed that this gene cluster from $P$. agglomerans $\mathrm{C} 1$ existed in eight Pantoea strains belonging to different species (P. eucrina, P. ananatis and P. agglomerans; Figure 1). Regardless of the absolute genetic distance among the genomes, the structure of the heavy metal resistance gene (MRG) cluster was conserved, and the overall nucleotide sequence identity of the $23.9-\mathrm{Kb}$ region ranged from $96 \%$ to $98 \%$ (Figure 3).

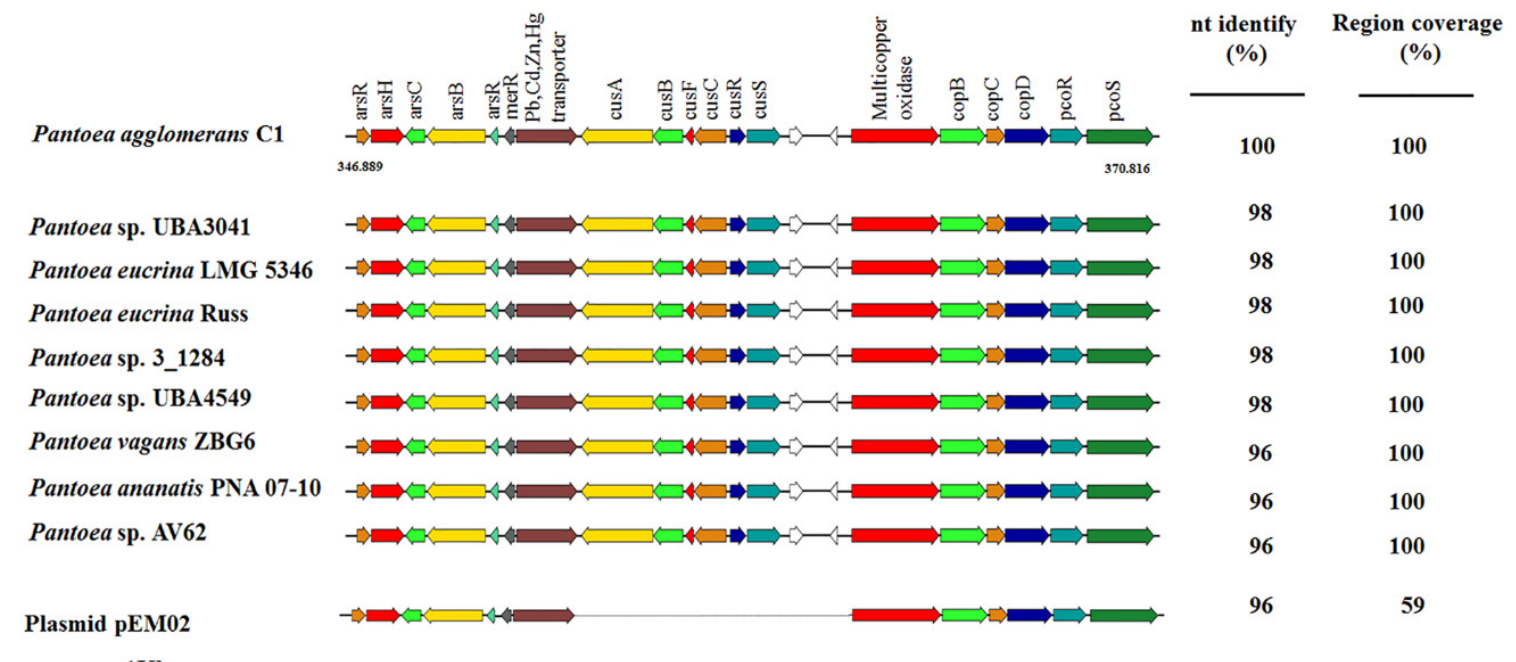

$-1 \mathrm{~Kb}$

Figure 3. Organization of the heavy metal gene (MRG) cluster of P. agglomerans $\mathrm{C} 1$ and comparison with other Pantoea genomes that have the same 19-gene cluster and with pEM02 plasmid from Erwinia sp. EM595 (GenBank reference: LN907829.1). Genes with unknown function are indicated in white. Genome accession numbers are reported in Supplementary Table S1.

This high degree of sequence identity and their location on a GI (at least on strain C1) suggests that the acquisition of these genes can occur upon horizontal gene transfer (HGT) events.

In order to determine potential selective advantage, due to the three ars gene clusters, we evaluated the maximum tolerable concentration (MTC) of P. agglomerans $\mathrm{C} 1$ for arsenate and arsenite. Data reported in Figure 4 (panel A) indicate that strain $\mathrm{C} 1$ was able to grow in medium amended with arsenate $(\mathrm{As}(\mathrm{V}))$ up to $100 \mathrm{mM}$, while E. coli control strain grew up to $20 \mathrm{mM}$.

In contrast, no difference was observed for As(III) MTC; both strains grew in medium containing arsenite up to $1 \mathrm{mM}$ (Figure 4, panel B). Our findings confirmed that the ars genes confer a competitive advantage to $\mathrm{C} 1$ cells growing in the presence of $\mathrm{As}(\mathrm{V})$ and indicated that the minimal inhibitory concentration (MIC) of this strain for arsenate was similar to that reported for P. agglomerans IMH [56] and arsenate-reducing bacteria isolated from arsenic-contaminated sites [57]. 

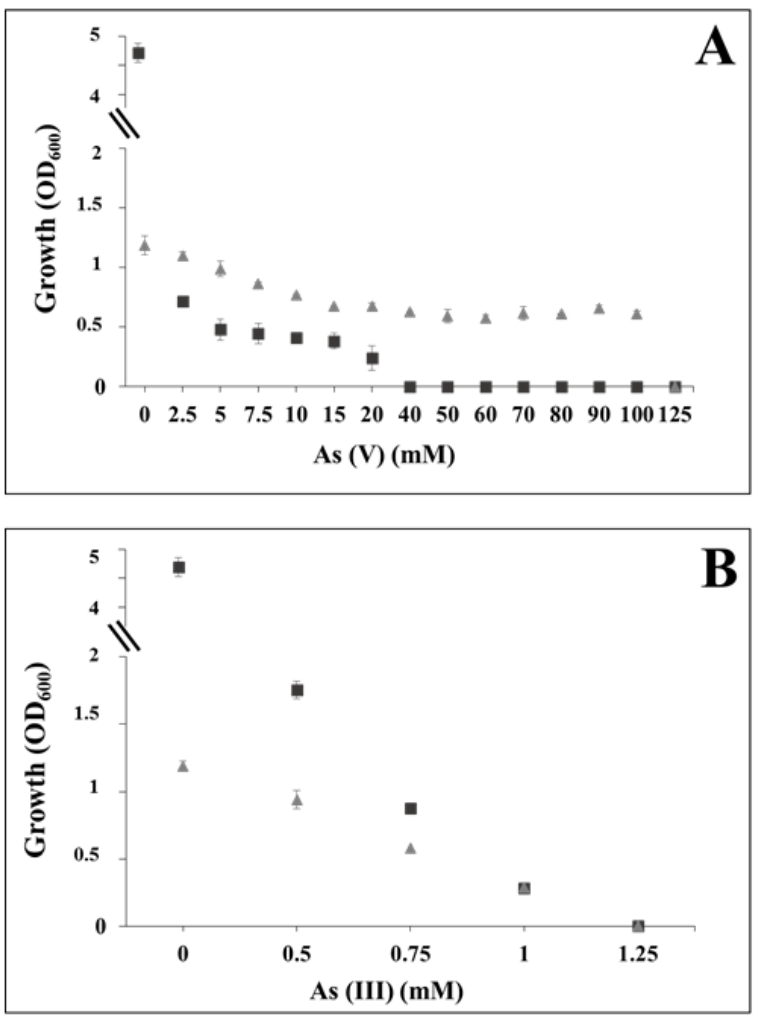

E. coli JM109 $\triangle$ P. agglomerans C1

Figure 4. Growth of P. agglomerans C1 and E. coli K12 derivative JM109 in LB medium supplemented with increasing concentrations of arsenate, $\mathrm{As}(\mathrm{V})(\mathbf{A})$, and arsenite, $\mathrm{As}(\mathrm{III})$ (B).

\section{Conclusions}

In conclusion, we demonstrated that metabolites produced by P. agglomerans $\mathrm{C} 1$ elicit promotion of plant growth, and the complete genome provides useful insights into the mechanisms underlying the PGP-traits. Importantly, the functional analysis of P. agglomerans C1 genome suggested that this strain has the potential to survive and grow in environments contaminated by heavy metals and can be used as a plant growth-promoting bacterium in heavy metal polluted soils. Finally, we provided evidence that strain $\mathrm{C} 1$ probably acquired the genes related to resistance to toxic metals by horizontal gene transfer.

Furthermore, the identification of several genes contributing in plant growth-promotion (i.e., lateral root development, pathogen resistance, and alleviation of oxidative, osmotic and acidic stresses) and conferring plant resistance to heavy metals (i.e., arsenic, copper, cadmium), strengthens the use of P. agglomerans $\mathrm{C} 1$ in reduction of biotic and abiotic stress response in heavy metals polluted soil, by improving plant growth performance.

Supplementary Materials: The following are available online at http://www.mdpi.com/2076-2607/8/2/153/s1, Figure S1: Representation of genomic islands predicted by IslandViewer 4 in the P. agglomerans C1 genome. The arrow indicates the location of the MRG cluster, Table S1: List of accession numbers for genomes utilized for phylogenetic analysis, Table S2: Predicted genomic islands in P. agglomerans C1. GI with sequence length $>20,000 \mathrm{bp}$ are highlighted in gold.

Author Contributions: Conceptualization, F.L., A.G.F. and M.R.; methodology, F.L., A.G.F., M.C. and M.R.; software, F.L., A.G.F. and M.R.; validation, F.L., A.G.F., M.C. and M.R.; formal analysis, M.R.; investigation, F.L., A.G.F., M.C., F.M., A.C. and M.R; resources, M.R.; data curation, F.L., A.G.F. and M.R.; writing-original draft preparation, F.L., A.G.F. and M.R.; writing—review and editing, F.L., A.G.F., M.C., F.M. and M.R.; visualization, F.L., A.G.F. and M.R.; supervision, M.R.; project administration, M.R.; funding acquisition, M.R. All authors have read and agreed to the published version of the manuscript.

Funding: This research received no external funding. 
Acknowledgments: This research did not receive any specific grant from funding agencies in the public, commercial, or not-for-profit sectors.

Conflicts of Interest: The authors declare no conflict of interest.

\section{References}

1. Chibuike, G.U.; Obiora, S.C. Heavy metal polluted soils: Effect on plants and bioremediation methods. Appl. Environ. Soil Sci. 2014, 2014. [CrossRef]

2. Glick, B.R. Using soil bacteria to facilitate phytoremediation. Biotechnol. Adv. 2010, 28, 367-374. [CrossRef] [PubMed]

3. Tak, H.I.; Ahmad, F.; Babalola, O.O. Advances in the application of plant growth-promoting rhizobacteria in phytoremediation of heavy metals. Rev. Environ. Contam. Toxicol. 2013, 223, 33-52.

4. Ruzzi, M.; Aroca, R. Plant growth-promoting rhizobacteria act as biostimulants in horticulture. Sci. Hortic. 2015, 196, 124-134. [CrossRef]

5. Rouphael, Y.; Colla, G. Synergistic biostimulatory action: Designing the next generation of plant biostimulants for sustainable agriculture. Front. Plant Sci. 2018, 9, 1655. [CrossRef]

6. Tirry, N.; Tahri Joutey, N.; Sayel, H.; Kouchou, A.; Bahafid, W.; Asri, M.; El Ghachtouli, N. Screening of plant growth promoting traits in heavy metals resistant bacteria: Prospects in phytoremediation. J. Genet. Eng. Biotechnol. 2018, 16, 613-619. [CrossRef]

7. IARC Working Group on the Evaluation of Carcinogenic Risks to Humans. Arsenic and arsenic compounds. In Arsenic, Metals, Fibres, and Dusts; IARC Monographs on the Evaluation of Carcinogenic Risks to Humans Volume 100C; IARC: Lyon, France, 2012; pp. 41-93.

8. ATSDR. CERCLA Priority List of Hazardous Substances for 2017; Agency for Toxic Substances and Disease Registry, Department of Health and Human Services: Atlanta, GA, USA, 2017. Available online: https: //www.atsdr.cdc.gov/SPL/\#2017spl (accessed on 16 February 2019).

9. Shankar, S.; Shanker, U. Arsenic contamination of groundwater: A review of sources, prevalence, health risks, and strategies for mitigation. Sci. World J. 2014, 2014. [CrossRef]

10. Hughes, M.F.; Beck, B.D.; Chen, Y.; Lewis, A.S.; Thomas, D.J. Arsenic exposure and toxicology: A historical perspective. Toxicol. Sci. 2011, 123, 305-332. [CrossRef]

11. Mukhopadhyay, R.; Rosen, B.P. Arsenate reductases in prokaryotes and eukaryotes. Environ. Health Perspect. 2002, 110 (Suppl. 5), 745-748. [CrossRef] [PubMed]

12. Páez-Espino, D.; Tamames, J.; De Lorenzo, V.; Cánovas, D. Microbial responses to environmental arsenic. Biometals 2009, 22, 117-130.

13. Lakshmanan, V.; Cottone, J.; Bais, H.P. Killing two birds with one stone: Natural rice rhizospheric microbes reduce arsenic uptake and blast infections in rice. Front. Plant Sci. 2016, 7, 1514. [CrossRef] [PubMed]

14. Wang, L.; Wang, J.; Jing, C. Comparative genomic analysis reveals organization, function and evolution of ars genes in Pantoea spp. Front. Microbiol. 2017, 8, 471. [CrossRef] [PubMed]

15. Zhang, Y.; Qiu, S. Examining phylogenetic relationships of Erwinia and Pantoea species using whole genome sequence data. Antonie Leeuwenhoek 2015, 108, 1037-1046. [CrossRef] [PubMed]

16. Walterson, A.M.; Stavrinides, J. Pantoea: Insights into a highly versatile and diverse genus within the Enterobacteriaceae. FEMS Microbiol. Rev. 2015, 39, 968-984. [CrossRef] [PubMed]

17. Dutkiewicz, J.; Mackiewicz, B.; Lemieszek, M.K.; Golec, M.; Milanowski, J. Pantoea agglomerans: A mysterious bacterium of evil and good. Part IV. Beneficial effects. Ann. Agric. Environ. Med. 2016, 23, 206-222. [CrossRef]

18. Luziatelli, F.; Ficca, A.G.; Colla, G.; Švecová, E.; Ruzzi, M. Effects of a protein hydrolysate-based biostimulant and two micronutrient-based fertilizers on plant growth and epiphytic bacterial population of lettuce. Acta Hortic. 2016, 1148, 43-48. [CrossRef]

19. Luziatelli, F.; Ficca, A.G.; Colla, G.; Baldassarre Švecová, E.; Ruzzi, M. Foliar application of vegetal-derived bioactive compounds stimulates the growth of beneficial bacteria and enhances microbiome biodiversity in lettuce. Front. Plant Sci. 2019, 10, 60. [CrossRef]

20. Coil, D.; Jospin, G.; Darling, A.E. A5-miseq: An updated pipeline to assemble microbial genomes from Illumina MiSeq data. Bioinformatics 2015, 31, 587-589. [CrossRef]

21. Luziatelli, F.; Ficca, A.G.; Melini, F.; Ruzzi, M. Genome sequence of the Plant Growth-Promoting Rhizobacterium (PGPR) Pantoea agglomerans C1. Microbiol. Resour. Announc. 2019, 8, e00828-19. [CrossRef] 
22. Aziz, R.K.; Bartels, D.; Best, A.A.; DeJongh, M.; Disz, T.; Edwards, R.A.; Formsma, K.; Gerdes, S.; Glass, E.M.; Kubal, M.; et al. The RAST server: Rapid annotations using subsystems technology. BMC Genom. 2008, 9, 75. [CrossRef]

23. Brettin, T.; Davis, J.J.; Disz, T.; Edwards, R.A.; Gerdes, S.; Olsen, G.J.; Olson, R.; Overbeek, R.; Parrello, B.; Pusch, G.D.; et al. RASTtk: A modular and extensible implementation of the RAST algorithm for building custom annotation pipelines and annotating batches of genomes. Sci. Rep. 2015, 5, 8365. [CrossRef] [PubMed]

24. Overbeek, R.; Begley, T.; Butler, R.M.; Choudhuri, J.V.; Chuang, H.Y.; Cohoon, M.; De Crecy-Lagard, V.; Diaz, N.; Disz, T.; Edwards, R.; et al. The subsystems approach to genome annotation and its use in the project to annotate 1000 genomes. Nucleic Acids Res. 2005, 33, 5691-5702. [CrossRef] [PubMed]

25. Price, M.N.; Dehal, P.S.; Arkin, A.P. FastTree 2-approximately maximum-likelihood trees for large alignments. PLoS ONE 2010, 5, e9490. [CrossRef]

26. Yoon, S.H.; Ha, S.M.; Lim, J.; Kwon, S.; Chun, J. A large-scale evaluation of algorithms to calculate average nucleotide identity. Antonie Leeuwenhoek 2017, 110, 1281-1286. [CrossRef] [PubMed]

27. Carattoli, A.; Zankari, E.; Garcia-Fernandez, A.; Voldby Larsen, M.; Lund, O.; Villa, L.; Aarestrup, F.M.; Hasman, H. PlasmidFinder and pMLST: In silico detection and typing of plasmids. Antimicrob. Agents Chemother. 2014, 58, 3895-3903. [CrossRef] [PubMed]

28. Zhou, Y.; Liang, Y.; Lynch, K.H.; Dennis, J.J.; Wishart, D.S. PHAST: A fast phage search tool. Nucleic Acids Res. 2011, 39, W347-W352. [CrossRef]

29. Arndt, D.; Grant, J.; Marcu, A.; Sajed, T.; Pon, A.; Liang, Y.; Wishart, D.S. PHASTER: A better, faster version of the PHAST phage search tool. Nucleic Acids Res. 2016, 44, W16-W21. [CrossRef]

30. Wu, S.; Zhu, Z.; Fu, L.; Niu, B.; Li, W. WebMGA: A customizable web server for fast metagenomic sequence analysis. BMC Genom. 2011, 12, 444. [CrossRef]

31. Bertelli, C.; Laird, M.R.; Williams, K.P.; Lau, B.Y.; Hoad, G.; Winsor, G.L.; Brinkman, F.S.L. IslandViewer 4: Expanded prediction of genomic islands for larger-scale datasets. Nucleic Acids Res. 2017, 45, W30-W35. [CrossRef]

32. Patten, C.L.; Glick, B.R. Role of Pseudomonas putida indoleacetic acid in development of the host plant root system. Appl. Environ. Microbiol. 2002, 68, 3795-3801. [CrossRef]

33. Schwyn, R.; Neilands, J.B. Universal chemical assay for detection and determination of siderophores. Anal. Biochem. 1987, 160, 47-56. [CrossRef]

34. Hrynkiewicz, K.; Baum, C.; Leinweber, P. Density, metabolic activity, and identity of cultivable rhizosphere bacteria on Salix viminalis in disturbed arable and landfill soils. J. Plant Nutr. Soil Sci. 2010, 173, 747-756. [CrossRef]

35. Alexander, D.B.; Zuberer, D.A. Use of chrome azurol S reagents to evaluate siderophore production by rhizosphere bacteria. Biol. Fertil. Soils 1991, 12, 39-45. [CrossRef]

36. Colla, G.; Rouphael, Y.; Canaguier, R.; Svecova, E.; Cardarelli, M. Biostimulant action of a plant-derived protein hydrolysate produced through enzymatic hydrolysis. Front. Plant Sci. 2014, 5, 448. [CrossRef] [PubMed]

37. Lehman, S.M. Development of a Bacteriophage-Based Biopesticide for Fire Blight. Ph.D. Thesis, Brock University, St. Catharines, ON, Canada, 2007.

38. Tatusov, R.L.; Fedorova, N.D.; Jackson, J.D.; Jacobs, A.R.; Kiryutin, B.; Koonin, E.V.; Krylov, D.M.; Mazumder, R.; Mekhedov, S.L.; Nikolskaya, A.N.; et al. The COG database: An updated version includes eukaryotes. BMC Bioinf. 2003, 4, 41. [CrossRef]

39. Zhang, P.; Jin, T.; Kumar Sahu, S.; Xu, J.; Shi, Q.; Liu, H.; Wang, Y. The distribution of tryptophan-dependent indole-3-acetic acid synthesis pathways in bacteria unraveled by large-scale genomic analysis. Molecules 2019, 24, 1411. [CrossRef]

40. Xie, S.S.; Wu, H.J.; Zang, H.Y.; Wu, L.M.; Zhu, Q.Q.; Gao, X.W. Plant growth-promotion by spermidine-producing Bacillus subtilis OKB105. Mol. Plant Microbe Interact. 2014, 27, 655-663. [CrossRef]

41. Santos-Beneit, F.; Rodríguez-García, A.; Franco-Domínguez, E.; Martín, J.F. Phosphate-dependent regulation of the low- and high-affinity transport systems in the model actinomycete Streptomyces coelicolor. Microbiology 2008, 154, 2356-2370. [CrossRef] 
42. Sashidhar, B.; Podile, A.R. Mineral phosphate solubilization by rhizosphere bacteria and scope for manipulation of the direct oxidation pathway involving glucose dehydrogenase. J. Appl. Microbiol. 2010, 109, 1-12. [CrossRef]

43. Ryu, C.M.; Farag, M.A.; Hu, C.H.; Reddy, M.S.; Wei, H.X.; Pare, P.W.; Kloepper, J.W. Bacterial volatiles promote growth in Arabidopsis. Proc. Natl. Acad. Sci. USA 2003, 8, 4927-4932. [CrossRef]

44. Lua, X.; Jia, G.; Zonga, H.; Zhugea, B. The role of budABC on 1,3-propanediol and 2,3-butanediol production from glycerol in Klebsiella pneumoniae CICIM B0057. Bioengineered 2016, 7, 439-444. [CrossRef] [PubMed]

45. Loper, J.E.; Hassan, K.A.; Mavrodi, D.V.; Davis, E.W.I.I.; Lim, C.K.; Shaffer, B.T.; Paulsen, I.T. Comparative genomics of plant-associated Pseudomonas spp.: Insights into diversity and inheritance of traits involved in multitrophic interactions. PLoS Genet. 2012, 8, e1002784. [CrossRef] [PubMed]

46. Sayyed, R.Z.; Chincholkar, S.B.; Reddy, M.S.; Gangurde, N.S.; Patel, P.R. Siderophore producing PGPR for crop nutrition and phytopathogen suppression. In Bacteria in Agrobiology: Disease Management; Maheshwari, D., Ed.; Springer: Berlin/Heidelberg, Germany, 2013; pp. 449-471.

47. Cao, J.; Woodhall, M.R.; Alvarez, J.; Cartron, M.L.; Andrews, S.C. EfeUOB (YcdNOB) is a tripartite, acid-induced and CpxAR-regulated, low-pH Fe ${ }^{2+}$ transporter that is cryptic in Escherichia coli $\mathrm{K}-12$ but functional in E. coli O157:H7. Mol. Microbiol. 2007, 65, 857-875. [CrossRef] [PubMed]

48. Rezzonico, F.; Smits, T.H.; Montesinos, E.; Frey, J.E.; Duffy, B. Genotypic comparison of Pantoea agglomerans plant and clinical strains. BMC Microbiol. 2009, 9, 204. [CrossRef] [PubMed]

49. Chang, J.S.; Yoon, I.H.; Kim, K.W. Arsenic biotransformation potential of microbial arsH responses in the biogeochemical cycling of arsenic-contaminated groundwater. Chemosphere 2018, 191, 729-737. [CrossRef] [PubMed]

50. Ben Fekih, I.; Zhang, C.; Li, Y.P.; Zhao, Y.; Alwathnani, H.A.; Saquib, Q. Distribution of Arsenic Resistance Genes in Prokaryotes. Front. Microbiol. 2018, 9, 2473. [CrossRef]

51. Garbinski, L.D.; Rosen, B.P.; Chen, J. Pathways of arsenic uptake and efflux. Environ. Int. 2019, 126, 585-597. [CrossRef]

52. Outten, F.W.; Huffman, D.L.; Hale, J.A.; O'Halloran, T.V. The independent cue and cus systems confer copper tolerance during aerobic and anaerobic growth in Escherichia coli. J. Biol. Chem. 2001, 276, 30670-30677. [CrossRef]

53. Silver, S.; Phung, L.T. Bacterial heavy metal resistance: New surprises. Annu. Rev. Microbiol. 1996, 50, 753-789. [CrossRef]

54. Brown, N.L.; Barrett, S.R.; Camakaris, J.; Lee, B.T.; Rouch, D.A. Molecular genetics and transport analysis of the copper-resistance determinant (pco) from Escherichia coli plasmid pRJ1004. Mol. Microbiol. 1995, 17, 1153-1166. [CrossRef]

55. Mergeay, M.; Monchy, S.; Vallaeys, T.; Auquier, V.; Benotmane, A.; Bertin, P.; Taghavi, S.; Dunn, J.; Van der Lelie, D.; Wattiez, R. Ralstonia metallidurans, a bacterium specifically adapted to toxic metals: Towards a catalogue of metal-responsive genes. FEMS Microbiol. Rev. 2003, 27, 385-410. [CrossRef]

56. Wu, Q.; Du, J.; Zhuang, G.; Jing, C. Bacillus sp. SXB and Pantoea sp. IMH, aerobic As(V)-reducing bacteria isolated from arsenic-contaminated soil. J. Appl. Microbiol. 2013, 114, 713-721. [CrossRef] [PubMed]

57. Anderson, C.; Cook, G. Isolation and characterization of arsenate-reducing bacteria from arsenic-contaminated sites in New Zealand. Curr. Microbiol. 2004, 48, 341-347. [CrossRef] [PubMed]

(C) 2020 by the authors. Licensee MDPI, Basel, Switzerland. This article is an open access article distributed under the terms and conditions of the Creative Commons Attribution (CC BY) license (http://creativecommons.org/licenses/by/4.0/). 